International Journal of Instruction

e-ISSN: 1308-1470 • www.e-iji.net

Article submission code:

20200325132034

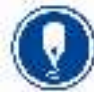

Received: $25 / 03 / 2020$

Revision: 04/12/2020
July $2021 \bullet$ Vol.14, No.3

p-ISSN: 1694-609X

pp. $175-186$

Accepted: 26/12/2020

OnlineFirst: 24/04/2021

\title{
Does The Use of APOS Theory Promote Students' Achievement in Elementary Linear Algebra?
}

\section{Made Arnawa}

Prof., corresponding author, Universitas Andalas, Indonesia, arnawa1963@gmail.com

\section{Yanita}

Dr., Universitas Andalas, Indonesia, yanita3010@gmail.com

\section{Yerizon}

Dr., Universitas Negeri Padang, Indonesia, yerizon@fmipa.unp.ac.id

\section{Bukti Ginting}

M.Sc., Universitas Andalas, Indonesia, ginting.suka54@gmail.com

\section{Sri Nita}

M.Sc., Politeknik Negeri Padang, Indonesia, srinita0610@gmail.com

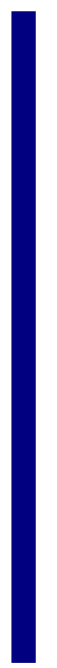

The study examines the impact of APOS theory on students' achievement in Elementary Linear Algebra (ELA) in accordance with their adequate prior knowledge (APK) and inadequate prior knowledge (IAPK). The mixed methods were used to determine the problem-solving test in ELA. Data were obtained from 65 industrial engineering students at Andalas University that enrolled in the 2019 Matrix and Vector Space course. A total of 35 students were in the experimental class and 30 in the control class. In the experimental class, students learning ELA was based on the APOS theory, and in the control class, it was based on the traditional approach. The result showed that: (1) students learning with ELA based on APOS theory is not yet satisfactory; (2) learning ELA based on APOS theory differs significantly compared to the traditional approach; (3) with APK in learning ELA based on APOS theory differs significantly compared to the traditional approach; (4) with IAPK in learning ELA based on APOS theory differs significantly compared to the traditional approach; (5) the APOS theory approach is suitable for both IAPK and APK in increasing students' achievement in ELA; (6) Students' levels of understanding in learning ELA based on APOS theory was better than the traditional approach

Keywords: elementary linear algebra, student' achievement, prior knowledge, APOS theory, traditional teaching and learning approach, quasi-experimental research

Citation: Arnawa, I. M., Yanita., Yerizon., Ginting, B., \& Nita, S. (2021). Does The Use of APOS Theory Promote Students' Achievement in Elementary Linear Algebra?. International Journal of Instruction, 14(3), 175-186. https://doi.org/10.29333/iji.2021.14310a 


\section{INTRODUCTION}

Elementary Linear Algebra (ELA) is an important academic course due to its wide application in the field of science, technology, and economics (Strang, 2016; Abdurrahman et al., 2019; Abdurrahman, Umaru, Abdullah, \& Osman, 2020). ELA is one of the compulsory courses of the Mathematics Department at Andalas University. However, every year, students' achievement in ELA has not been in line with academic expectations, with only $43 \%$ graduating with a grade of B and mean scores that do not exceed 70. One of the causes of these poor grades is due to students' difficulty in problem-solving questions. For example, many students have difficulty selecting methods suitable for system of linear equations (Arnawa, Yerizon, \& Nita, 2019a). Some studies have also shown similar results, in the weakness of students' understanding of the concepts in ELA and related traits ( Stewart \& Thomas, 2010; Wawro, 2014; 2015; Salgado \& Trigueros, 2015; Berman \& Shvartsman, 2016; Bagley \& Rabin, 2016). According to Berman \& Shvartsman (2016), students have difficulty in understanding the concepts in ELA, such as span, linear independence, and basis (Stewart \& Thomas, 2010), eigenvalues, eigenvectors, and eigenspaces (Salgado \& Trigueros, 2015), as well as the criteria for a matrix, to have an inverse (Wawro, 2014). They also find it difficult to coordinate the three modes of thinking associated with the ELA problem-solving. These include computational, abstract, and geometric (Bagley \& Rabin, 2016) and the weak solution of $A x=b$ (Wawro, 2015).

In the traditional teaching and learning approach (TRAD), ELA is taught with an axiomatic approach, i.e. by using definitions, theorems, examples, and exercises. According to Dorier and Sierspinska (2001), an axiomatic approach in teaching ELA seems to be unsuitable for most students. Aidyn (2009) stated that several factors need to be prioritized by lecturers for learning to run successfully, i.e. (1) considering students' prior knowledge in introducing mathematics concepts, (2) discussing a concept in different ways. For example, Worter and Meyers (1998), presented a simple algorithm to determine eigenvalues and eigenvectors elegantly without using determinants, (3) considering the mental construction of students in understanding a mathematical concept. For example, Dubinsky (1997), introduced the mental construction action, process, object, and schema (APOS), (4) paying attention to teaching strategies. For example, Harel (2000), introduced three keywords for learning ELA, namely concrete, necessity, and generalisability, (5) involving the use of computers in learning. Herero (2000) stated that a computer is intended to assist students in making definitions, theorems, and solving various problems. Many lecturers have used computers to improve students' achievement and retention abilities (Lahcen \& Mohapatra, 2020).

There are many instructional learning designs for teaching ELA (Talbert, 2014; Cárcamo, Fuentealba, \& Garzón, 2019). Talbert (2014) suggested using flipped classrooms to increase student success in learning ELA. Meanwhile, Cárcamo et al. (2019) promoted the use of LIT on learning ELA, especially for the concepts of the spanning set. The APOS theory approach is one of the frameworks for the development of an instructional learning design for teaching mathematics at the college level 
(Dubinsky, 1991; 1997; Dubinsky \& McDonald, 2001). This theory is a structure of mental and learning approach used to categorize students' level of understanding in mathematics, starting from the lowest (actions) to the highest (schemas). The APOS theory approach has the following characteristics (1) embracing constructivism, (2) paying attention to the student's mental construction in understanding a mathematical concept, (3) using a computer, (4) providing cooperative learning, (5) using the learning cycle, i.e. activity, classroom discussion, and exercise (ACE) (Arnon et al., 2014). As a learning approach, the APOS theory utilizes Aidyn analysis (2009).

Several studies have been conducted on learning mathematics based on APOS theory (Afgani, Suryadi, \& Dahlan, 2017; Syamsuri, Purwanto, Subanji, \& Irawati 2017; Borji, Alamolhodaei, \& Radmehr, 2018; Naglea, Planellb, \& Russoc, 2019; Arnawa, Yerizon, Nita, \& Putra, 2019; Arnawa, Yerizon, \& Nita, 2019b). Naglea et al. (2019) proposed the APOS-slope framework to be used to understand students' difficulties in learning slope, based on the theoretical perspective. Syamsuri et al. (2017) and Afgani et al. (2017) stated that many students were still at the structure of mental 'action conception' in learning mathematics. APOS theory approach improves students' achievement in learning (i) derivative (Borji et al., 2018), (ii) system of linear equations (Arnawa et al., 2019), and abstract algebra (Arnawa et al., 2019b).

One of the factors that greatly determines student success in learning mathematics is prior knowledge (Kiwanuka, Damme, Noortgate, Anumendem, \& Namusisi, 2015; Aminah, Kusumah, Suryadi, \& Sumarmo, 2018; Hailikari, Nevgi, \& Komulainen, 2008). This provides valuable insight into students' future performance; therefore, it is essential to choose learning strategies suitable for all types of prior knowledge possessed by students. Few studies pay attention to prior knowledge in learning the ELA in Indonesia; therefore, it is essential to carry out this research. Based on the factors affecting achievement in mathematics, such as the teaching model, and prior knowledge, this study is intended to answer the following research questions (1) Does the use of APOS theory promote students' achievement in ELA?; (2) Does the use of APOS theory promote students' achievement in ELA, both for those with adequate and inadequate prior knowledge? (3) Is there an interaction between the teaching and the prior knowledge factors toward achievement in ELA? (4) Does the use of APOS theory promote students' levels of understanding in ELA?

\section{METHOD}

This research utilized mixed methods. Firstly, the quantitative research method with the quasi-experimental control group post-test design was used to compare the effectiveness of the APOS theory with a traditional approach in improving students' achievement in ELA. Secondly, the qualitative research method was used to categorize the students' level of understanding in ELA into one of the four mental structures of APOS.

The participants of this research were 65 students consisted of 35 students in the experiment class (EC) and 30 students in control class (CC), they were taking part in ELA Courses, the academic year 2019 at Andalas University. The EC was taught ELA based on the APOS theory using the following main stages: (1) the lecturer gave a brief explanation of the course, (2) 4 to 5 students, tend to actively involve in group 
discussions to understand definitions, theorems, solve problems, and provide examples in their worksheet. At this stage, lecturers act as facilitators to encourage students, (3) lecturers, together with students, analyze these exercises with the help of Maple software. Meanwhile, the $\mathrm{CC}$ was taught based on the traditional learning with the following main stages: (1) lecturers convey the materials in the form of definitions, theorems, and examples, (2) they allow students to ask questions (3) lecturers asked students to work on the exercise individually. In both classes, the researcher act as a lecturer.

The research instruments used were: (1) students' worksheet which contains learning activities that are alleged to be able to improve their competence in ELA, (2) lesson plans based on the APOS theory approach which consists of semi-detailed lecture guide for teaching and learning ELA. Lesson plans and student worksheets have been explicitly compiled through development research by Arnawa et al. (2019), which met valid, practical, and effective criteria. (3) test in ELA consisting of 4 items for assessing students' conceptual understanding by using the APOS mental structure, developed by Arnawa et al. (2019). Each question is rated from 0 to 10 following the completeness and accuracy of students'answers.

Data sources of this research consisted of primary data and secondary data. Primary data in the form of students' achievement in ELA was obtained through the test conducted after the experiment. Secondary data in the form of students' achievement in calculus was gathered from the lecturer of calculus at Andalas University. This secondary data was used to group students into adequate prior knowledge (APK) and inadequate prior knowledge (IAPK) based on their graduation rate at the calculus (calculus was a prerequisite material for ELA). When the calculus grade of students is at $\mathrm{B}$ or above, then they are grouped into APK, and when the opposite occurs, they are grouped into IAPK.

Data analysis used in this research was quantitative data analysis i.e. t-test and the twoway analysis of variance (ANOVA) and qualitative data analysis. The t-test was used to compare EC and CC on students' achievement in ELA and ANOVA was used to check if there was an interaction between the teaching and the prior knowledge factors toward achievement in ELA. All data were analyzed using SPSS 17 at the .05 level of significance. The qualitative data analysis was used to categorize students into one of the four mental structures of APOS. Based on the completeness and accuracy of students'answers (score of 8 or more), students' level of conceptual understanding in ELA are grouped as follows: (1) action level (only test 1 was correct); (2) process level (test 1 and 2 were correct, but test 3 and 4 were incorrect); (3) object level (test 1, 2 and 3 were correct, but test 4 was incorrect); (4) schema level (test 1, 2, 3, and 4 were correct). Students that cannot be categorized as action, process, object, and schema levels were tagged uncategorized (US).

\section{FINDINGS}

To obtain an overview of students' achievement in ELA, the research data were presented in the form of minimum (Xmin) and maximum values (Xmax), mean, standard deviation (SD), and many students $(\mathrm{N})$ as shown in Table 1. 
Table 1

Statistics descriptive of students' achievement in ELA

\begin{tabular}{llllll}
\hline Data & $\mathrm{N}$ & Xmin & Xmax & Mean & SD \\
\hline All score tests & 65 & 10 & 40 & 27.5077 & 7.75831 \\
\hline
\end{tabular}

Table 1 shows that students' mean score in ELA in $0-100$ scales only reaches $\frac{27.5077}{40}$ $\mathrm{x} 100=68.76925$ (less than 70 ); therefore, it still belongs to the unsatisfactory category.

In order to answer the first research question, all data in the experimental and control groups in the form of Xmin, Xmax, mean, SD, and a number of students (N) are shown in Table 2.

Table 2

Statistics descriptive of students' achievement in ELA reviewed from methods of teaching

\begin{tabular}{llllll}
\hline Method of Teaching & $\mathrm{N}$ & Xmin & Xmax & Mean & SD \\
\hline TRAD & 30 & 10 & 36 & 23.8000 & 7.90199 \\
\hline APOS & 35 & 13 & 40 & 30.6857 & 6.12503 \\
\hline
\end{tabular}

Table 2 shows that the mean score of students, which are based on APOS theory, is higher and more uniform than the TRAD approach. Using SPSS 17, the two-way ANOVA test results are shown in Table 3.

Table 3

The result of two-way ANOVA for teaching methods

\begin{tabular}{lllllll}
\hline Source & Sum of Squares & Df & Mean Square & F statistics & Sig. & Decision \\
\hline Teaching & 744.327 & 1 & 744.327 & 3256.449 & .011 & $\begin{array}{l}\text { The differences } \\
\text { were significant } \\
\text { Methods }\end{array}$ \\
& & & & & & $(0.05>.011)$ \\
\hline
\end{tabular}

From Tables 2 and 3, it can be concluded that the mean score of students' taught with the APOS theory, significantly differed from the traditional approach.

To answer the second research question, all data in the IAPK and APK were in the form of Xmin, Xmax, mean, SD, and a number of students (N), as shown in Table 4.

Table 4

Statistics descriptive on students' achievement in ELA reviewed from methods of teaching and prior knowledge

\begin{tabular}{lllllll}
\hline Prior & TRAD & \multicolumn{5}{l}{ APOS } \\
\cline { 2 - 7 } Knowledge & Mean & SD & N & Mean & SD & N \\
\hline IAPK & 22.0000 & 8.06226 & 13 & 28.7333 & 6.58425 & 15 \\
\hline APK & 25.1765 & 7.73171 & 17 & 32.1500 & 5.47025 & 20 \\
\hline
\end{tabular}

Table 4 shows that the (1) mean score of students with APK and learning ELA based on APOS was higher than those on TRAD. (2) The mean score of students with IAPK and learning ELA based on APOS was higher than those based on TRAD. Using SPSS 17, the two-independent sample t-test results are expressed as in Tables 5 and 6. 
Table 5

The result of two independent sample t-tests with adequate prior knowledge of students' mean score with learning is based on TRAD and APOS

\begin{tabular}{llll}
\hline t-statistic & Df & Sig. (2-tailed) & Decision \\
\hline-2.433 & 26 & .022 & The differences were significant $(0.05>.022)$ \\
\hline
\end{tabular}

Table 6

The result of two independent sample t-tests with inadequate prior knowledge students' mean score with learning based on TRAD and APOS

\begin{tabular}{llll}
\hline $\mathrm{t}$-statistic & Df & Sig. (2-tailed) & Decision \\
\hline-3.202 & 35 & .003 & The differences were significant $(0.05>.003)$ \\
\hline
\end{tabular}

From Tables 5 and 6, it can be concluded that (1) mean score of students with APK and learning ELA with APOS was significantly higher than those learning ELA with TRAD, (2) mean score of students with inadequate prior knowledge (IAPK) and learning ELA with APOS theory was significantly higher than those learning ELA with TRAD.

Figure 1 is an interaction diagram used to answer the third research question.

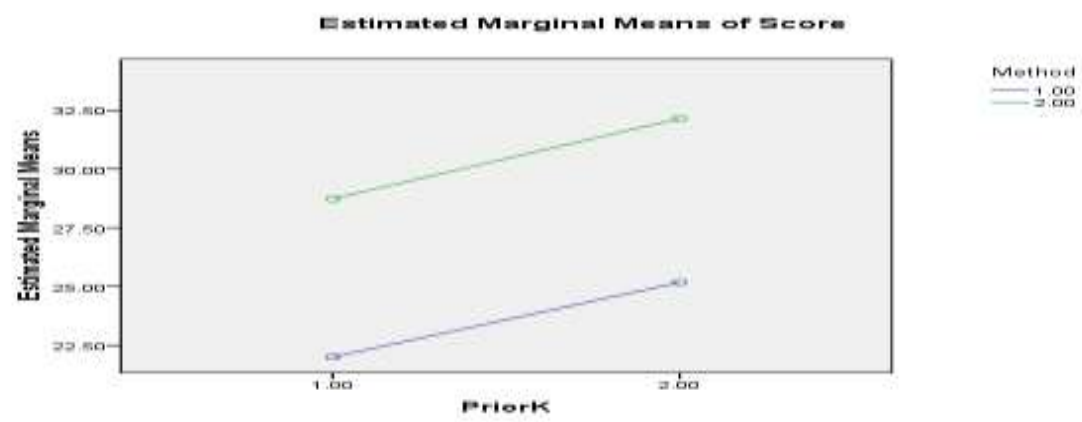

Figure 1

Interaction diagram between the PriorK factor and the Method

Figure 1 shows that the methods of learning factors do not interact with the prior knowledge factors (PriorK), and it is matched with the two-way ANOVA test, as shown in Table 7.

Table 7

The result of two-way ANOVA for interaction

\begin{tabular}{|c|c|c|c|c|c|c|}
\hline Source & Sum of Squares & $\overline{\mathrm{Df}}$ & Mean Square & F statistics & Sig. & Decision \\
\hline $\begin{array}{l}\text { Learning Method } \\
\text { and Prior } \\
\text { Knowledge }\end{array}$ & .229 & 1 & .229 & .005 & .945 & $\begin{array}{l}\text { The interaction was } \\
\text { not significant } \\
(0.05<.945)\end{array}$ \\
\hline
\end{tabular}

Based on Table 7, it can be concluded that the APOS theory is suitable for students with APK and IAPK.

To answer the fourth research question, all students in the APOS and TRAD groups were categorized into one of the four mental structures in ELA, i.e action, process, object, schema, as shown in Table 8. 
Table 8

Number and percentage of students at each level of understanding reviewed from teaching methods

\begin{tabular}{lllll}
\hline Mental & APOS & & TRAD & \\
\cline { 2 - 5 } Structure & Number of students & Percentage & Number of students & Percentage \\
\hline Action (1) & 1 & $2.78 \%$ & 6 & $20 \%$ \\
\hline Process (2) & 4 & $11.43 \%$ & 8 & $26.67 \%$ \\
\hline Object (3) & 11 & $31.43 \%$ & 10 & $33.33 \%$ \\
\hline Schema (4) & 19 & $54.39 \%$ & 6 & $20 \%$ \\
\hline US (0) & 0 & 0 & 0 & 0 \\
\hline
\end{tabular}

The index level of understanding an experiment $\left(\mathrm{I}_{\mathrm{APOS}}\right)$ and control class $\left(\mathrm{I}_{\mathrm{TRAD}}\right)$ can be calculated from Table 8 .

$$
\mathrm{I}_{\mathrm{APOS}}=\frac{1.1+4.2+11.3+19.4}{35}=3.37 \text { and } \mathrm{I}_{\mathrm{TRAD}}=\frac{6.1+8.2+10.3+6.4}{30}=2.53 \text {. }
$$

$I_{A P O S}$ is higher than $I_{T R A D}$. This means that the level of understanding in the experiment class was better than the control class.

\section{DISCUSSION}

Table 1 showed that the average of students' achievement in ELA in the scale of 0-100 was 68.76925; therefore, the majority of students have difficulties in learning ELA. The student's answer sheet showed that the most difficult topics were the eigenvalue, eigenvector, and their application in the diagonalization of a matrix. This is in line with the research conducted by Salgado \& Trigueros (2015). Students' success in determining eigenvalues and eigenvectors is highly dependent on their level of understanding in determinant, the roots of a polynomial, and their ability to determine the solution of a system of linear equations that has many solutions. Why is the achievement of students' that were learning ELA based on APOS theory significantly better than the traditional approach? And why is the achievement of students with IAPK or IAPK learning ELA based on APOS theory, significantly better than the traditional approach?, There are at least three fundamental answers to these questions.

First, the APOS theory embraces constructivism (Arnon et al., 2014), which changes mathematics learning radically. Vintere (2018), stated that students are active in constructing their knowledge while lecturers only act as facilitators (Bhowmik, 2015). This means that the theorems on the concepts in the ELA are found by students, while lecturers facilitate them by creating a classroom environment free from intimidation and fear (Ampadu \& Danso, 2018). Also, in this research, lecturers prepare a lesson plan and student worksheets based on characteristics of the APOS theory. In this case, lesson plans and student worksheets have been explicitly compiled through development research by Arnawa et al. (2019), which met valid, practical, and effective criteria. Therefore, students are greatly assisted in understanding the ELA concepts, which ultimately improve their achievement. According to Galia (2016), students taught based on the constructivism got higher gain scores compared to those taught with the traditional method. 
Secondly, in the APOS theory, students learning ELA are required to share their opinion and have the same responsibilities in solving mathematical problems (Chan \& Idris, 2017). During the lecture process, a lecturer serves in the role of facilitator and always motivates and encourages students. Cooperative learning does not only increase academic achievement (Tinungki, 2017; Maelasari \& Wahyudin; 2017; Karali \& Aydemir, 2018). It also leads to a rise in attitudes toward mathematics (Hobri et al., 2018).

Thirdly, the APOS theory involves the use of computers in learning. In this study, computers are not just used to check the truth of students' answers on exercise, but it is also used to obtain data for them to generalize theorems. The use of computers in teaching and learning increases student interest and achievement in mathematics (Zakaria \& Khalid, 2016; Witte, Haelermans, \& Rogge, 2014; Eyyam \& Yaratan, 2014; Lashley, 2017; Radović, Marić, \& Passey, 2019).

ELA is a course that demands prerequisite material. Therefore, students' level of mastery of prerequisite material is used to predict their learning success. Students' prior knowledge needs to be taken into account when considering instructional strategies for teaching and learning mathematics (Aidyn, 2009; Hohensee, 2014; 2016).

Table 7 showed that the methods of learning do not interact with the prior knowledge factor. This means that in the APOS theory, students with IAPK and APK found a suitable environment to optimize their ELA achievements. The implication of this study is APOS theory can be used in teaching mathematics without regard to prior knowledge. This is because learning interacts with several factors that determine student outcomes. Santyasa, Rapi, \& Sara (2020) and Sæle, Dahl, Sørlie, \& Friborg (2016) stated that learning models interact with academic procrastination towards students' achievement.

\section{CONCLUSIONS}

Based on data analysis, it can be concluded that students' level of achievement (1) is not yet satisfactory; (2) learning ELA based on APOS theory differs significantly compared to the traditional approach; (3) with APK in learning ELA based on APOS theory differs significantly compared to the traditional approach; (4) with IAPK in learning ELA based on APOS theory differs significantly compared to the traditional approach; (5) the APOS theory approach is suitable for both IAPK and APK in increasing students' achievement in ELA; (6) Students' levels of understanding in learning ELA based on APOS theory was better than the traditional approach.

\section{ACKNOWLEDGMENT}

This research was supported by Andalas University under the research contract number: T/6/UN.16.17/PP.IS-KRP1GB/LPPM/2019

\section{REFERENCES}

Abdurrahman, M.S., Abdullah, A.H., Osman, S., Ali, D.F., Samah, N.A., Jumaat, N.F., ..., Kohar, U.H.A. (2019). A systematic review on the impact of peer tutoring strategy in 
linear algebra among polytechnic students, Journal of Critical Reviews, 6(5), 298-305. https://doi.org/10.31838/jcr.07.06.52

Abdurrahman, M.S., Umaru, W., Abdullah, A.H., \& Osman, S. (2020). Effect of peer tutoring strategy on students academic performance in a polytechnic linear algebra classroom. Jour of Adv Research in Dynamical \& Control Systems, 12(3), 415- 422. https://doi.org/ 10.5373/JARDCS/V12I3/20201209

Afgani, M.W., Suryadi, D. \& J A Dahlan, J.A. (2017). Analysis of undergraduate students' mathematical understanding ability of the limit of function based on APOS theory perspective. Journal of Physics: Conf. Series, 895(1). https://doi.org/10.1088/1742-6596/895/1/012056

Aminah, M., Kusumah, Y. S., Suryadi, D., \& Sumarmo, U. (2018). The effect of metacognitive teaching and mathematical prior knowledge on mathematical logical thinking ability and self-regulated learning. International Journal of Instruction, 11(3), 45-62. https://doi.org/10.12973/iji.2018.1134a

Ampadu, E. \& Danso, A. (2018) Constructivism in mathematics classrooms: Listening to Ghanaian teachers' and students' views. Africa Education Review, 15(3), 49-71. https://doi.org/10.1080/18146627.2017.1340808

Arnawa, I.M., Yerizon, Nita, S. (2019a). Errors and misconceptions in learning elementary linear algebra. Journal of Physics: Conference Series, 1321(2). https://doi.org/10.1088/1742-6596/1321/2/022095

Arnawa, I.M., Yerizon, Nita S., \& Putra, R.T. (2019). Development of students' worksheet based on APOS theory approach to improve student achievement in learning system of linear equations. International journal of scientific \& technology research, $8(4), 287-292$.

Arnawa, I.M., Yerizon, \& Nita, S. (2019b). Improvement students' level of proof ability in abstract algebra through APOS theory approach. International Journal of Scientific \& Technology Research, 8(7), 128-131.

Arnon, I., Cottrill, J., Dubinsky, E., Oktaç, A., Roa Fuentes, S., Trigueros, M., Weller. K. (2014). APOS Theory: A framework for research and curriculum development in mathematics education. New York: Springer Verlag. https://doi.org/10.1007/978-14614-7966-6

Aydin, S. (2009). The factors affecting teaching linear algebra. Procedia Social and Behavioral Sciences, 1, 1549-1553. https://doi.org/10.1016/j.sbspro.2009.01.272

Bagley, S. \& Rabin, J. M. ( 2016). Students' use of computational thinking linear algebra. International Journal of Research in Undergraduate Mathematics Education, 2(1), 83-104. https://doi.org/10.1007/s40753-015-0022-x

Berman, A. \& Shvartsman, L. (2016). Definitions are important: The case of linear algebra. European Journal of Science and Mathematics Education, 4(1), 26-32. 
Bhowmik, M. (2015). Constructivism approach in mathematics teaching and assessment of mathematical understanding. Basic Research Journal of Education Research and Review, 4(1), 8-12.

Borji, V., Alamolhodaei, H. \& Radmehr, F. (2018). Application of the APOS-ACE theory to improve students' graphical understanding of derivative. EURASIA Journal of Mathematics, Science and Technology Education, 14(7), 2947-296. https://doi.org/10.29333/ejmste/91451

Cárcamo, A., Fuentealba, C., \& Garzón, D. (2019). Local instruction theories at the university level: An example in a linear algebra course. EURASIA Journal of Mathematics, Science and Technology Education, 15(12), 1-16. https://doi.org/10.29333/ejmste/108648

Chan, L.L. \& Idris, N. (2017). Cooperative learning in mathematics education. International Journal of Academic Research in Business and Social Sciences, 7(3), 539553. https://doi.org/10.6007/IJARBSS/v7-i3/2757

Dorier J.L.\& Sierpinska A. (2001). Research into the teaching and learning of linear algebra. In: Holton D., Artigue M., Kirchgräber U., Hillel J., Niss M., Schoenfeld A. (eds) The Teaching and Learning of Mathematics at University Level. New ICMI Study Series, vol 7. Springer, Dordrecht. https://doi.org/10.1007/0-306-47231-7_24

Dubinsky, E. (1991). Reflective abstraction in advanced mathematical thinking. In D. O. Tall (Ed.), Advanced mathematical thinking (pp. 95-123). Dordrecht: Kluwer Academic Publishers.

Dubinsky, E. (1997). Some thoughts on the first course in linear algebra at the college level. In D. Carlson, C. Johnson, D. Lay, A. D. Porter, A. Watkins, \& W. Watkins (Eds.), Resources for teaching linear algebra (pp. 85-106). MAA notes volume 42, Washington, DC: The Mathematical Association of America.

Dubinsky, E., \& McDonald, M. (2001). APOS: A constructivist theory of learning. In D. Holton (Ed.) The teaching and learning of mathematics at university level: An ICMI study (pp. 275-282). Dordrecht, The Netherlands: Kluwer Academic Publishers.

Eyyam, R. \& Yaratan, H.S. (2014). Impact of the use of technology in mathematics lessons on student achievement and attitudes. Social Behavior and Personality, 42(1), 31-42. https://doi.org/10.2224/sbp.2014.42.0.S31

Galia, M.L.D (2015). Constructivist-based approach in teaching mathematics: A quasiexperimental study. Research Journal of Educational Sciences, 4(10), 1-4.

Hailikari, T., Nevgi, A. \& Komulainen, E. (2008). Academic self-beliefs and prior knowledge as predictors of student achievement in Mathematics: a structural model, Educational Psychology, 28(1), 59-71. https://doi.org/10.1080/01443410701413753

Harel, G. (2000). Principles of learning and teaching mathematics, with particular reference to the learning and teaching of linear algebra: Old and new observations. In Dorier, J.L. (Ed.), On the teaching of linear algebra (pp. 177-189). The Netherlands: Kluwer Academic Publishers 
Herrero, M.P. (2000). Strategies and computer projects for teaching linear algebra. International Journal of Mathematics Education and Science Technology, 31(2), 181186.

Hobri, Dafik, \& Hossain, A.(2018). The Implementation of learning together in improving students' mathematical performance. International Journal of Instruction, 11(2), 483-496. https://doi.org/10.12973/iji.2018.11233a

Hohensee, C. (2014). Backward transfer: An investigation of the influence of quadratic functions instruction on students' prior ways of reasoning about linear functions. Mathematical Thinking and Learning, 16(2), 135-174. https://doi.org/10.1080/10986065.2014.889503

Hohensee, C. (2016). Teachers' awareness of the relationship between prior knowledge and new learning. Journal for Research in Mathematics Education, 47(1), 17-27. https://doi.org/10.5951/jresematheduc.47.1.0017

Karali, Y. \& Aydemir, H. (2018). The effect of cooperative learning on the academic achievement and attitude of students in Mathematics class. Educational Research and Reviews, 3(21), 712-722. https://doi.org/10.5897/ERR2018.3636

Kiwanuka, H. N., Damme, J.V, Noortgate, W.V.D, Anumendem, D.N., \& Namusisi, S. (2015). Factors affecting Mathematics achievement of first-year secondary school students in Central Uganda. South African Journal of Education, 35(3), 1-16. https://doi.org/10.15700/SAJE.V35N3A1106

Lahcen, R. A. M. \& Mohapatra, R. (2020). Promoting Proactive Behavior through Motivation: Required Math Lab Hours Case. International Journal of Research in Education and Science, 6(1), 111-119.

Lashley, L. (2017). The Effects of Computer-aided instruction in mathematics on the performance of grade 4 pupils, Sage Open, 7(3), 1-12. https://doi.org/10.1177\%2F2158244017712775

Maelasari, E. \& Wahyudin (2017). Effects of cooperative learning STAD on mathematical communication ability of elementary school student, Journal of Physics: Conference Series, 895(1). https://doi.org/10.1088/1742-6596/895/1/012090

Naglea, C., Planellb, R. M., \& Russoc, D.M. (2019). Using APOS theory as a framework for considering slope understanding. Journal of Mathematical Behavior, 54, 1-14. https://doi.org/10.1016/j.jmathb.2018.12.003

Radović, S., Marić, M. \& Passey, D. (2019). Technology enhancing mathematics learning behaviors: Shifting learning goals from "producing the right answer" to "understanding how to address current and future mathematical challenges". Education and Information Technologies, 24, 103-126. https://doi.org/10.1007/s10639-0189763-x

Sæle, R. G., Dahl, T. I., Sørlie, T., \& Friborg, O. (2016). Relationships between learning approach, procrastination and academic achievement amongst first-year university students. Higher Education, 74(5), 757-774. 
Salgado, H. \& Trigueros, M. (2015). Teaching eigenvalues and eigenvectors using models and APOS Theory. The Journal of Mathematics Behaviour, 39,100-120. https://doi.org/10.1016/j.jmathb.2015.06.005

Santyasa, I. W., Rapi, N. K., \& Sara, I. W. W. (2020). Project-based learning and academic procrastination of students in learning physics. International Journal of Instruction, 13(1), 489-508.https://doi.org/10.29333/iji.2020.13132a

Syamsuri, Purwanto, Subanji, \& Irawati, S. (2017). Using APOS theory framework: Why did students unable to construct a formal proof? International Journal on Emerging Mathematics $\quad$ Education, $\quad 1(2), \quad 135-146$. https://doi.org/10.12928/ijeme.v1i2.5659

Stewart, S. \& Thomas, M. O. J. (2010). Student learning of basis, span and linear independence in linear algebra. International Journal of Mathematical Education in Science and Technology, 41(2), 173-188. https://doi.org/10.1080/00207390903399620

Strang, G. (2016). Introduction to Linear Algebra, 5th ed. Cambridge: WellesleyCambridge Press.

Talbert, R. (2014). Inverting the linear algebra classroom. PRIMUS, 24(5), 361-374. https://doi.org/ 10.1080/10511970.2014.883457

Tinungki, G. M. (2017). The role of cooperative with team assisted individualization to improve the students' self proficiency. Journal of Science and Science Education, 1(2), 63-73. https://doi.org/10.24246/josse.v1i2p63-73

Vintere, A. (2018). A constructivist approach to the teaching of mathematics to boost competencies needed for sustainable development. Rural Sustainability Research, 39(334), 1-6. https://doi.org/10.2478/plua-2018-0001

Wawro, M. (2014). Student reasoning about the invertible matrix theorem in linear algebra. ZDM Mathematics Education, 46, 389-406.

Wawro, M. (2015). Reasoning about solutions in linear algebra: The case of Abraham and the invertible matrix theorem. International Journal of Research in Undergraduate Mathematics Education, 1, 315-338. 1, 315-338. https://doi.org/10.1007/s40753-0150017-7

Witte, D. K., Haelermans, C. \& Rogge, N. (2014). The effectiveness of a computerassisted math learning program. Journal of Computer Assisted Learning, 31(4), 314329. https://doi.org/10.1111/jcal.12090

Worter, W.A.M. \& Meyers, L.F. (1998). Computing eigenvalues and eigenvectors $\begin{array}{llll}\text { without determinants. } & \text { Mathematics } & \text { Magazine, }\end{array}$ https://doi.org/10.1080/0025570X.1998.11996591

Zakaria, N. and Khalid, F. (2016) The benefits and constraints of the use of information and communication technology (ICT) in teaching mathematics. Creative Education, 7, 1537-1544. https://doi.org/10.4236/ce.2016.711158 